\title{
Sources and levels of trihalomethanes in Suez bay water: Attaka power station (case study)
}

\author{
Yosry A. Soliman \\ National Institute of Oceanography and Fisheries
}

\begin{abstract}
Trihalomethanes have been identified as one of the most important disinfection byproducts resulted from using hypochlorite in power stations. So, Attaka power station was chosen as a case study which used hypochlorite as biological fouling control in its cooling seawater system. Water samples were collected monthly during 2016-2017 from four sits in the inlet, outlet, after dosing hypocrite and at mixing point. The seawater samples were analyzed for water temperature, $\mathrm{pH}$ value, salinity, oxidizible organic matter, total residual chlorine and trihalomethanes (THM's). The results showed that the two main forms of THMs formed in the receiving seawater were broomcorn and dibromochloromethan. The broomcorn compound was fluctuated between $12.16 \mathrm{ppm}$ and $237.25 \mathrm{ppm}$ with a mean value of 77.23 ppm and with a total annual of $926.76 \mathrm{ppm}$, while dibromochloromethan ranged from 0.28 to $4.20 \mathrm{ppm}$. Significant positive correlation was found between trihalmethnes fractions and both of the measured concentrations of the total residual chlorine and organic matter, while negative correlations with water temperatures and $\mathrm{pH}$ values were noticed. No correlation between trihalomethanes and salinity was recorded.
\end{abstract}

Key words: Trihalomethanes, residual chlorine, Attaka power station, disinfection byproducts.

\section{INTRODUCTION}

The power stations, desalination plants and oil refineries which built on the sea shore coast and depend on seawater in their cooling systems suffer from the growth and reproduction of marine fouling organisms in tunnels and pipelines of their cooling system causing blocking and clogging the entrance of seawater, which leads to the inefficiency of the station of electricity and often come out of operation (Fisher et al., 1991; Videla, 1995). Power stations and desalination stations use several methods to resist marine fouling organisms, for example adding hypochlorite to seawater at the entrance of the power plant (Sakaguchi et al., 1989; Katranitsas et al., 2003).One of the harmful effects on marine environment is the chemical reaction between the total residual chlorine come out from these power plants and the organic matter in seawater, forming Trihalomethans (Kampioti and Stephanou, 2002). The presence of bromine in seawater leads to the formation of bromoform, which has a significant effect on the growth of some marine fouling organism (Saeed et al., 1999).. Bromine is formed by the oxidation of bromide by chlorination, leading to the formation of bromine compounds. THMs in chlorinated seawater mainly consist of bromoform $\mathrm{CHBr}$ (Sakaguchi et al., 1989), dibromochoromethan $\mathrm{CHBr} 2 \mathrm{Cl}$, dichorobromomethan $\mathrm{CHBrCl}_{2}$, choroform $\mathrm{CHCl}_{3}$ (Sakaguchi et al., 1989). Bromoform has a slow and progressive formation, being the final product in the oxidation of organic substances, and by research in the scientific references we did not find any reference or data 
Yosry A. Soliman

published about this point in the area under investigation, but there are many studies and researches in other parts of the world (Parsons et al., 1984; Sugita et al., 1992).

\section{Study Area and sampling}

\section{MATERIALS AND METHODS}

Attaka power station located on the Suez bay coast (Suez Gulf), Egypt. Seawater was drawn from the sea to the power station at Attaka through tunnel and it was used for cooling the main condensers and auxiliary systems like the process seawater heat exchangers. Seawater was drawn (about $26 \mathrm{~m} 3 / \mathrm{sec}$ pumping seawater to the power station by 8 pumps) through a $500 \mathrm{~m}$ long submarine intake tunnel. The intake water was doused by hypochlorite solution to inhibit the biomass of fouling organisms. The outcome water from the condenser and processes seawater heat exchangers was discharged into the Suez bay seawater and mixed with the coastal water which characterized by strong tidal currents.

Surface seawater samples were collected monthly using Nansen bottle from four sites, inlet point site I (seawater of Suez bay), after dosing hypochlorite site II (seawater after injection of hypocrite solution)), outfall point III (seawater loaded by residual chorine and thermal pollution) and mixing point site IV (effluents after mixed with seawater) during the period November 2016-Septemeper 2017 (Fig. 1). The sampling point at the inlet point was located far from the intake water to devoid any chlorine and notionally representative of the ambient water body.

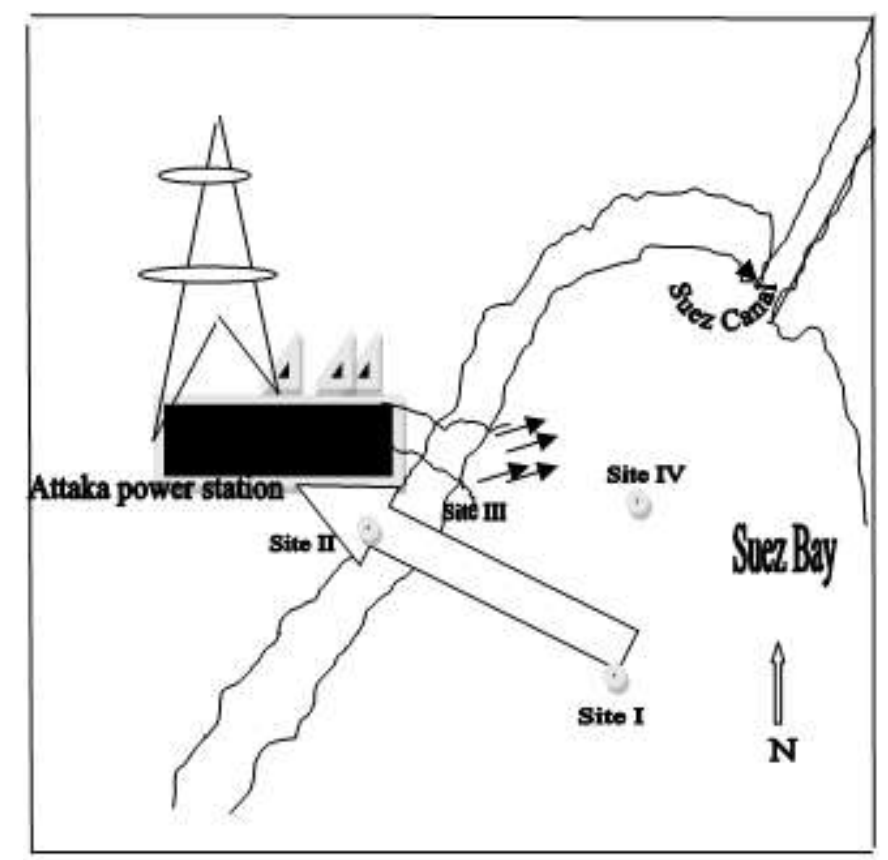

Fig.(1)Sampling stations in front of Attaka power station on the Suez bay coastal (not scaling).

\section{Determination of total residual chlorine and seawater characterization}

Free, combined and total chlorine concentrations were determined by colorimetric DPD method using a Thermo scientific Orion TM AQ3070 AQUA fast TM Chlorine Meter. 


\section{Sources and levels of trihalomethanes in Suez bay water: Attaka power station (case study)}

DPD free Chlorine package was added to $10 \mathrm{ml}$ of water sample where free available chlorine (Hypochlorous acid and the hypochlorite ion) in the sample oxidizes DPD causing a magenta red color. (Total Residual Chlorine $=$ Free Residual Chlorine + Combined Residual Chlorine).

\section{Determination of THMs}

THMs were quantified by liquid/liquid extraction with $n$-pentane with ratio $(5 \mathrm{ml}$ sample: $1 \mathrm{ml} \mathrm{n}$-pentane), and then shaking for $5 \mathrm{~min}$. Then $3 \mathrm{~L}$ of the extract was injected in gas chromatograph model Hewellet-Packard HP-5890 series II with Electron Capture Detector (ECD) according to Standard Method 6232 (APHA, 2005). Capillary column HP-1 with specifications, $30 \mathrm{~m}-0.53 \mathrm{~mm}$ ID and $0.5 \mathrm{~mm}$ film thicknesses was used in this study. Carrier and make-up gas was pure nitrogen (99.999\% purity).

\section{RESULTS AND DISCUSSION}

Five electric power stations were constructed on the northern part of the Gulf of Suez at the entrance of the Suez Canal. All the power stations depend on seawater in the their cooling systems. One of these stations, is Attaka power station which was chosen to study its outfall water loading by total residual chorine and its role in the formations of trihalomethanes. All these stations use the hypochlorite for the control of marine fouling organisms.

Attaka power station suffers from the fast and heavy growth of fouling organisms in its cooling system and tunnel which draw the seawater from the Suez Gulf to the entrance of the station. The fouling organisms causing the drop of efficiency of cooling system of this station and sometimes some of its units get out of work due the block of many of heat exchangers tubes by fouling organisms (about 40-65 tons of sessile marine organisms had to be removed from the pipeline during a single cleaning, personal communication). Monthly fouling biomass accumulated on PVC panels and wood panels at the entrance of Attaka power station has been studded by Soliman and Yassin (2007) and the results are summarized Table (1) and Figure (2).

Table (1). Monthly fouling biomass wet weight g/panel accumulated on PVC and wood panel at the inlet of seawater at the entrance of Attaka power station during 2006.

\begin{tabular}{|c|c|c|c|c|c|c|c|c|c|c|c|c|}
\hline Month & $\begin{array}{c}\text { Jan- } \\
2006\end{array}$ & $\begin{array}{c}\text { Feb- } \\
2006\end{array}$ & $\begin{array}{c}\text { Mar- } \\
2006\end{array}$ & $\begin{array}{c}\text { Apr- } \\
2006\end{array}$ & $\begin{array}{c}\text { May- } \\
2006\end{array}$ & $\begin{array}{c}\text { Jun- } \\
2006\end{array}$ & $\begin{array}{c}\text { Jul- } \\
2006\end{array}$ & $\begin{array}{c}\text { Aug- } \\
2006\end{array}$ & $\begin{array}{c}\text { Sep } \\
2006\end{array}$ & $\begin{array}{c}\text { Oct- } \\
2006\end{array}$ & $\begin{array}{c}\text { Nov- } \\
2006\end{array}$ & $\begin{array}{c}\text { Dec- } \\
2006\end{array}$ \\
\hline PVC & 19.0 & 185.0 & 82.0 & $167 / 0$ & 29.0 & 217.5 & 84.5 & 372.5 & 112.5 & 699.5 & 202.5 & 1009.5 \\
\hline Wood & 38.0 & 60.0 & 73.0 & 25.0 & 45.5 & 94.0 & 96.0 & 24.0 & 217.5 & 58.5 & 417.5 & 520.0 \\
\hline
\end{tabular}




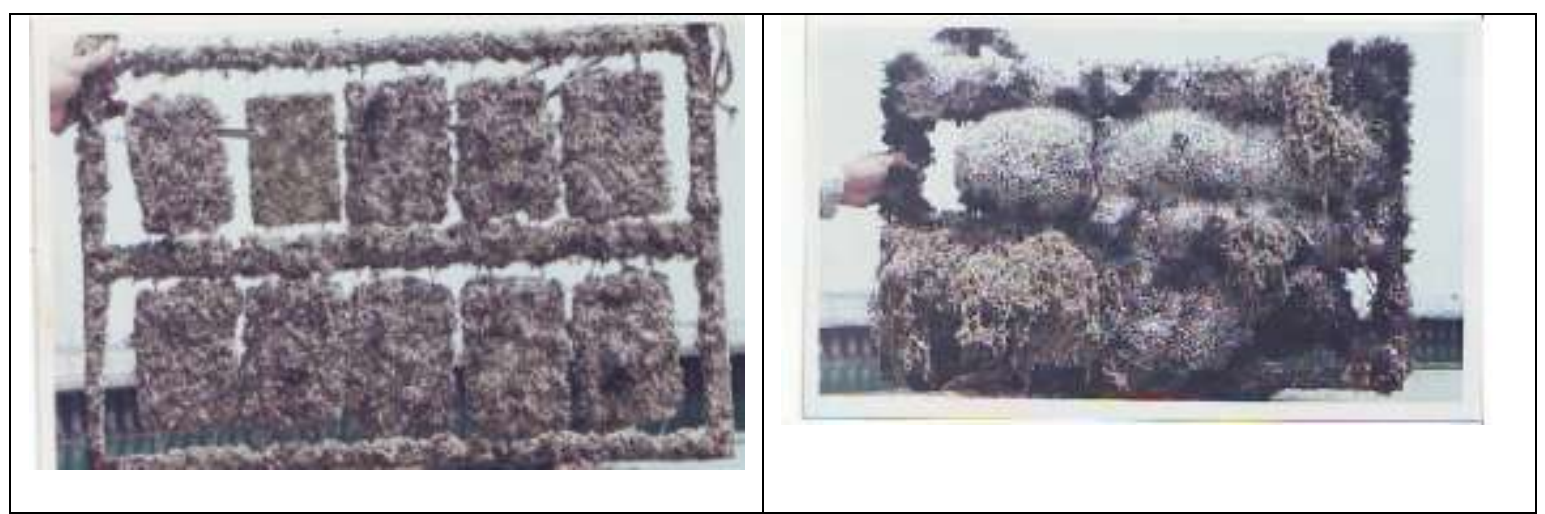

Fig. (2). Fouling organisms accumulated on PVC (1) and wood panel at the inlet of seawater at the entrance of Attaka power station during 2006.

Hypocrite was used to control the marine fouling organisms. The hypochlorite in Attatka power station was produced using dissociation of sodium choired which exist in seawater by electric cells containing platinum electrodes and the produced hypochlorite was injected in the cooling seawater at the inlet of power station on the sea. Active chlorine solutions, whether created hypochlorite's, or comprise one or more of three different speciesmolecular chlorine $\left(\mathrm{Cl}_{2}\right)$.

Some of the remaining chorine residual escape to the marine environment, where the residual chorine react with organic matter (the main source of organic matter coming from the wastewater treatment plant which pumping the treated wastewater to the sea thorough a tube far away from the beach by about 500m) forming the THMs (bromoform $\mathrm{CHBr} 3$, dibromochoromethan $\mathrm{CHBr} 2 \mathrm{Cl}$, dichorobromomethan $\mathrm{CHBrCl} 2$, choroform $\mathrm{CHCl} 3$ (Krasner et al., 1989) (Fig. 3).

Unfortunately, there were no studies before on the levels and sources of THMs in Suez bay as a result of using hypochlorite in the cooling systems in spite the presence of five power stations in the northern part of Suez Gulf which uses the same technology in control the fouling organism and this is the first case study which investigated this point. There are many studies in other areas addressed the significant effect of the organic matter on the chlorine residual as a source of halogenated organic compounds (Wong et al., 1977; Allonier et al., 1999).

Trihalomethanes (THMs) is produced by the reaction of the residual chlorine with organic matter in seawater (Nebo et al., 2006). The levels of trihalomethanes (THMs) depends on several factors, such as the water temperature, $\mathrm{pH}$ value, total residual chlorine....etc (Goodman, 1987; Iriarte et al., 2003; Acero et al., 2005; Rodriguez et al., 2007).

At Attaka power station, the characterization of seawater collected from the location near the inlet of cooling seawater indicated that the temperature values ranged between 18 


\section{Sources and levels of trihalomethanes in Suez bay water: Attaka power station (case study)}

and $27 \mathrm{C}^{\circ}$, $\mathrm{pH}$ between 8.0 and 8.2 , salinity between 41.5 and $42.98 \%$ and the particulate organic matter between 0.19 and $0.88 \mathrm{mg} / \mathrm{l}$ (Table 2).

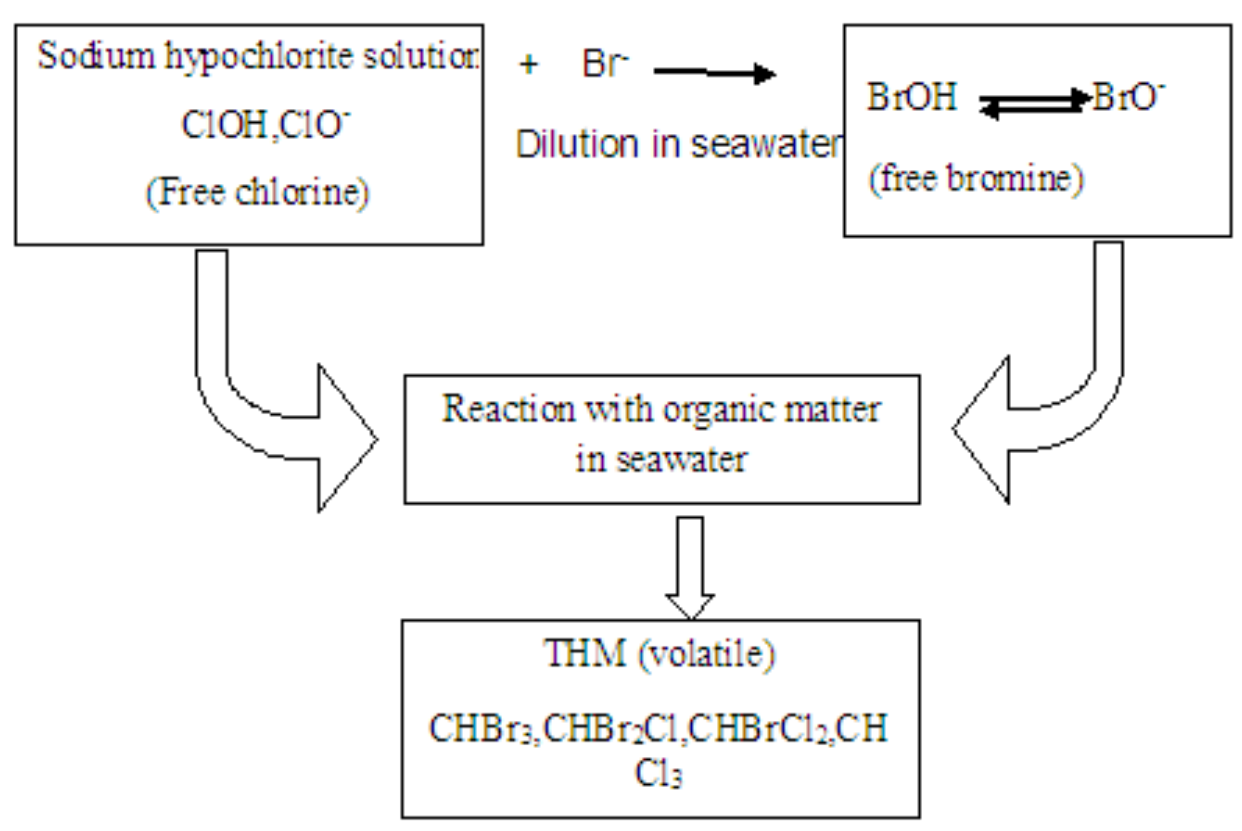

Fig. (3). The chemistry consequent upon sodium hypochlorite injection in natural seawater

Table (2). Seawater temperature $\left({ }^{\circ} \mathrm{C}\right), \mathrm{pH}$-value, salinity\%o and dissolved organic matter $\mathrm{mg} / \mathrm{l}$ of seawater in front of Attaka power station during 2016-2017

\begin{tabular}{|c|l|r|r|r|l|l|l|l|l|l|l|l|}
\hline $\begin{array}{c}\text { Rarameter } \\
\text { Date }\end{array}$ & $\begin{array}{l}\text { Nov- } \\
016\end{array}$ & $\begin{array}{r}\text { Dec- } \\
016\end{array}$ & $\begin{array}{r}\text { Jan- } \\
017\end{array}$ & $\begin{array}{l}\text { Feb- } \\
017\end{array}$ & $\begin{array}{l}\text { Mar- } \\
017\end{array}$ & $\begin{array}{l}\text { Apr- } \\
017\end{array}$ & $\begin{array}{l}\text { May- } \\
017\end{array}$ & $\begin{array}{l}\text { Jun- } \\
017\end{array}$ & $\begin{array}{l}\text { Jul- } \\
017\end{array}$ & $\begin{array}{l}\text { Aug- } \\
017\end{array}$ & $\begin{array}{l}\text { Sep- } \\
017\end{array}$ & $\begin{array}{l}\text { Oct- } \\
017\end{array}$ \\
\hline T C $^{\circ}$ & 19.58 & 18.94 & 18.3 & 17.5 & 18 & $\begin{array}{l}21.2 \\
5\end{array}$ & 24.03 & 26.8 & $\begin{array}{l}26 . \\
91\end{array}$ & 27.01 & 23.3 & $\begin{array}{l}22.1 \\
2\end{array}$ \\
\hline $\mathrm{pH}$ & 8.3 & 8.38 & 8.45 & 8.25 & 8.35 & 8.36 & 8.3 & 8.39 & $\begin{array}{l}8.4 \\
6\end{array}$ & 8.39 & 8.22 & 8.12 \\
\hline Salinity \%o & 42.35 & 42.98 & $\begin{array}{r}41.5 \\
3\end{array}$ & $\begin{array}{r}41.5 \\
3\end{array}$ & $\begin{array}{l}4 \\
5\end{array}$ & $\begin{array}{l}41.7 \\
7\end{array}$ & 41.06 & $\begin{array}{l}40.1 \\
5\end{array}$ & $\begin{array}{l}41 . \\
66\end{array}$ & 42.41 & $\begin{array}{l}41.1 \\
6\end{array}$ & 423 \\
\hline DOM mg/l & 1.55 & 1.27 & 1.29 & 0.88 & 0.76 & 0.65 & 0.28 & 0.91 & $\begin{array}{l}0.9 \\
6\end{array}$ & 0.99 & 1.00 & 0.88 \\
\hline
\end{tabular}

Temperature plays a vital role in speeding the kinetics reaction between chlorine redial and organic matter (Acero et al., 2015). There was a negative correlations between seawater temperatures and levels of total chorine residual at site II and site III, dibromochoromethan $\mathrm{CHBr}_{2} \mathrm{Cl}$ (Site II), broomcorn $\mathrm{CHBr}_{3}$ (Site II), dibromochoromethan $\mathrm{CHBr}_{2} \mathrm{Cl}$ (Site III) and broomcorn $\mathrm{CHBr}_{3}$ (Site IV). This may reflect the effect of temperature on the rate of evaporation of THMs which distinguished by low boiling point and low suability in water (Table 3).

There was also a negative inverse relationship between $\mathrm{pH}$ values and THMs compounds. An increase in $\mathrm{pH}$ results in a decrease in residual chlorine concentration and 


\section{Yosry A. Soliman}

consequently a decrease in the concentration of THMs compounds (Table 3). Nearly no correlation was found between salinity and trihalomethanes compounds. As for the effect of organic matter, it was found that there was a good relationship with most of THMs compounds.

Table (3). Relationship between total chlorine residual $(\mathrm{mg} / \mathrm{l})$, temperature $\left({ }^{\circ} \mathrm{C}\right), \mathrm{pH}$, salinity (\%o), particulate organic carbon $(\mathrm{mg} / \mathrm{l})$ of seawater and bromoform $(\mu \mathrm{g} / \mathrm{l})$

\begin{tabular}{|c|c|c|c|c|c|c|c|c|c|c|c|}
\hline & $\begin{array}{l}\mathrm{CHBr}_{2} \mathrm{Cl} \\
\text { Site II }\end{array}$ & $\begin{array}{l}\mathrm{CHBr}_{3} \\
\text { Site II }\end{array}$ & $\begin{array}{c}\mathrm{CHBr}_{2} \\
\text { Cl Site } \\
\text { III }\end{array}$ & $\begin{array}{c}\mathrm{CHBr}_{3} \\
\text { Site } \\
\text { III }\end{array}$ & $\begin{array}{c}\mathrm{CHBr}_{3} \\
\text { Site } \\
\text { IV }\end{array}$ & $\begin{array}{c}\text { residual } \\
\text { chlorine } \\
\text { Site II }\end{array}$ & $\begin{array}{l}\text { residual } \\
\text { chlorine } \\
\text { Site III }\end{array}$ & $\begin{array}{c}\mathrm{T} \\
\mathrm{C}^{\circ}\end{array}$ & $\mathrm{pH}$ & $\begin{array}{l}\text { Sal } \\
\% \text { o }\end{array}$ & $\begin{array}{c}\mathrm{DOM} \\
\mathrm{mg} / \mathrm{l}\end{array}$ \\
\hline $\mathrm{CHBr}_{2} \mathrm{ClSite} \mathrm{II}$ & 1.00 & & & & & & & & & & \\
\hline $\mathrm{CHBr}_{3}$ Site II & .19 & 1.00 & & & & & & & & & \\
\hline $\mathrm{CHBr}_{2}$ ClSite III & 1.00 & .19 & 1.00 & & & & & & & & \\
\hline $\mathrm{CHBr}_{3}$ Site III & -.41 & .57 & -.41 & 1.00 & & & & & & & \\
\hline $\mathrm{CHBr}_{3}$ Site IV & .52 & .52 & .52 & .26 & 1.00 & & & & & & \\
\hline $\begin{array}{l}\text { residual chlorine } \\
\text { Site II }\end{array}$ & .45 & .85 & .45 & .29 & .72 & 1.00 & & & & & \\
\hline $\begin{array}{l}\text { residual chlorine } \\
\text { Site III }\end{array}$ & .42 & .73 & .42 & .19 & .71 & .91 & 1.00 & & & & \\
\hline $\mathrm{T} \mathrm{C}^{\circ}$ & -.45 & -.01 & -.45 & .32 & -.56 & -.20 & -.32 & 1.0 & & & \\
\hline $\mathrm{pH}$ & -.47 & -.15 & -.47 & .20 & -.12 & -.30 & -.21 & .19 & 1.0 & & \\
\hline Salinity \%o & -.11 & .01 & -.11 & -.17 & -.34 & -.08 & -.07 & .01 & -.67 & 1.0 & \\
\hline DOM mg/l & .09 & .71 & .09 & .40 & .60 & .54 & .56 & -.28 & .18 & $\begin{array}{l}.07 \\
\end{array}$ & 1.00 \\
\hline
\end{tabular}

The levels of total residual chlorine and trihalomethanes (THMs) in Suez bay water at the investigated four sampling sits are given in Tables (4 \&5). It was obvious from Table (3), that the values of the total residual chlorine at sits I (Inlet seawater) and Site IV (Mixings point) lie under detection limit $(<0.1)$. At site II the total residual chlorine ranged between a minimum of 0.51ppm in November 2016 to a maximum of $0.11 \mathrm{ppm}$ in Feb, 2016, June 2017 and July 2017 with a mean value of $0.22 \mathrm{ppm}$ and with annual discharge about $2.71 \mathrm{ppm}$, while at site III the residual chlorine lies in the range $0.05-0.22 \mathrm{ppm}$, the minimum values were recorded in February-2017 and Aguest-2017 while the maximum one was noticed in Sep-017 with a mean value of $0.10 \mathrm{ppm}$ and total discharges about $1.24 \mathrm{ppm}$.

It was clear from Table (4) that trihalomethans at site I, are nearly not detected in most months and reached about $1.10 \mathrm{ppm}$ and $0.90 \mathrm{ppm}$ at Aug-017for dichlorobromomenane and bromoform, respectively. At site II, broomcorn fluctuated between 12.16ppm at Feb-016 and 237.25ppm at Nov-017 with a mean value of $77.23 \mathrm{ppm}$ and total annual of $926.76 \mathrm{ppm}$, Dibromochlorome than were found in levels of 4.20, 3.11, $3.02,4.01,2.14,0.28,3.12$ and $1.12 \mathrm{ppm}$, respectively while chloroform and dichlorobromoform are not found in all months of study. At Site III, only dibromochorome than and bromoform are found and ranked between a minimum of $2.14 \mathrm{ppm}$ for and 


\section{Sources and levels of trihalomethanes in Suez bay water: Attaka power station (case study)}

13.46ppm for dibromochorome than and bromoform, rspectivly at Jun-017and Apr-017 while a maximum values of 5.00 and 62.13ppm are found at Feb-017 and Aug-017 with a mean values reached about 3.31 and $42.36 \mathrm{ppm}$. At site IV, the dibromochorome than ranged from not detected to the maximum value (about 4.09 at Sept. 2017), while the total bromoform which enters the marine environment was about 232.13ppm during 2016-2017. The minimum value of $4.61 \mathrm{ppm}$ was observed at Oct-017, while the maximum value $(40.00 \mathrm{ppm})$ was noticed at Sept. 2017.

Table (5) indicated that the values of bromoform and dibromochlorome than were nearly detected at all sites. Chloroform is the major THMs formed at power stations used freshwater as source of cooling water, whereas bromoform is predominate at power stations used seawater as source of cooling water in estuarine and marine sites. On the other hand, seawater contains approximately $68 \mathrm{mg} / \mathrm{l}$ bromide at full salinity, when chlorine is added it oxidizes the bromide ions yielding hypobromous acid $\mathrm{HOBr}$. This reaction is rapid, with $99 \%$ conversion with 10 s at full seawater salinity and within 15 s even at half seawater salinity (full salinity of Suez bay water ranged between 41.5 and $42.98 \%$ ). The free oxidants formed by the chlorination of seawater are thus predominantly composed of $\mathrm{HOBr}$ and the hypobromite ion $\mathrm{OBr}^{-}$. At the ambient $\mathrm{pH}$ of seawater this free oxidant is essentially dissociated and consequently more efficient as a biocide than the dissociated $\mathrm{OCl}^{-}$. Seawater contains high concentrations of bromide ion opposite freshwater containing low concentrations and oxidizes active chlorine ion bromide to hypobromous acid $(\mathrm{HOBr})$ and hypobromite ion.

Table (4). Levels of residual chorine (mg/l) in inlet, outlet, afterdosing and mixing point in front of Attaka power station during 2016-2017

\begin{tabular}{|c|c|c|c|c|}
\hline $\begin{array}{c}\text { Month and } \\
\text { year }\end{array}$ & Site I & Site II & Site III & Site IV \\
\cline { 2 - 5 } & Inlet & $\begin{array}{c}\text { After dosing } \\
\text { hypochlorite }\end{array}$ & Outfall & Mixing Point \\
\hline Nov-016 & $<0.1$ & 0.51 & 0.18 & $<0.1$ \\
\hline Dec-016 & $<0.1$ & 0.28 & 0.18 & $<0.1$ \\
\hline Jan-017 & $<0.1$ & 0.22 & 0.11 & $<0.1$ \\
\hline Feb-017 & $<0.1$ & 0.11 & 0.05 & $<0.1$ \\
\hline Mar-017 & $<0.1$ & 0.13 & 0.08 & $<0.1$ \\
\hline Apr-017 & $<0.1$ & 0.22 & 0.10 & $<0.1$ \\
\hline May-017 & $<0.1$ & 0.17 & 0.06 & $<0.1$ \\
\hline Jun-017 & $<0.1$ & 0.11 & 0.05 & $<0.1$ \\
\hline Jul-017 & $<0.1$ & 0.11 & 0.07 & $<0.1$ \\
\hline Aug-017 & $<0.1$ & 0.17 & 0.05 & $<0.1$ \\
\hline Sep-017 & $<0.1$ & 0.49 & 0.22 & $<0.1$ \\
\hline Oct-017 & $<0.1$ & 0.19 & 0.09 & \\
\hline Mean & & 0.22 & 0.10 & \\
\hline Sum & & 2.71 & 1.24 & \\
\hline Mini & & .11 & 0.05 & \\
\hline Max & & .51 & 0.22 & \\
\hline St.def & & .13 & .058 & \\
\hline
\end{tabular}


Table (5). Levels of THMs ( $\mu \mathrm{g} / \mathrm{l})$ in inlet, outlet, after dosing and mixing point in front of Attaka power station during 2016-2017

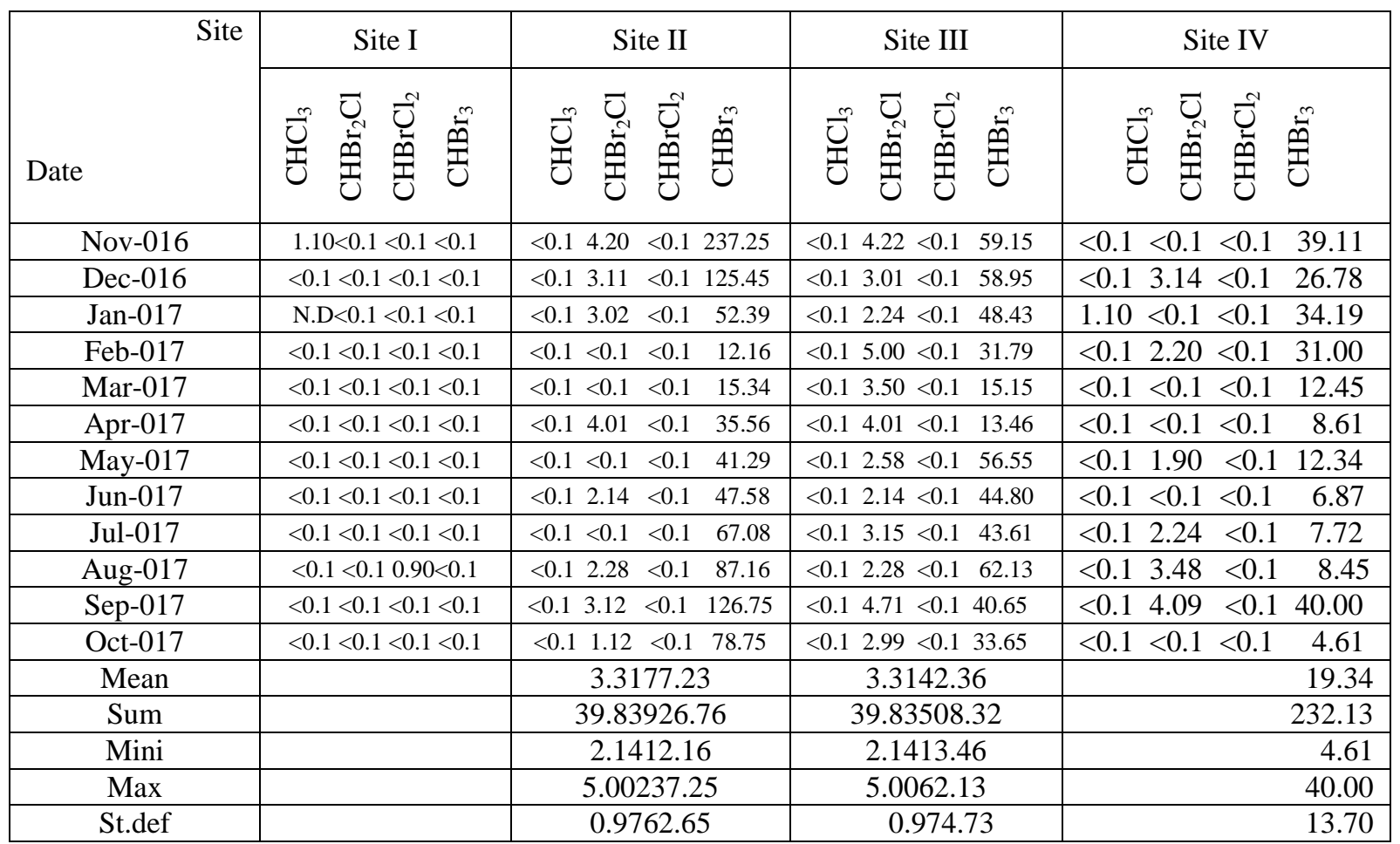

\section{REFERENCES}

Acero, J.L.; Piriou, P. and von Gunten, U. (2005). Kinetics and mechanisms of formation of romophenols during drinking water chlorination: assessment of taste and odor development. Water Res., 39 (13): 2979-2993.

Allonier, A.S.; Khalanski, M.; Camel, A. and Bermond, A. (1999). Characterization of chlorination by-product in cooling effluents of coastal nuclear power stations. Mar. Pollut. Bull.,38:1232-1241.

APHA (2005). Standard Methods for the Examination of Water and Wastewater. American Public Health Association, Washington, D.C.

Fisher, S.; Stromberg, P.; Bruner, K.A. and Boulet, L.D. (1991). Molluscicidal activity of potassium to the zebra mussel Dreissena polymorpha toxicity and mode of action. Aquat.Toxicol., 20:219-234.

Goodman, P.D. (1987). Effect of chlorine on materials for seawater cooling systems: a review of chemical reactions. Br. Corros. J., 70:56-62.

Iriarte, U.; Alvarez-Uriarte, J.I.; Lopez-Fonseca, R. and Gonzalez-Velasco, J.R. (2003). Trihalomethane formation in ozonated and chlorinated surface water. Environ. Chem. Lett., 1: 57-61.

Kampioti, A.A. and Stephanou, E.G.(2002). The impact of bromide on the formation of neutral and acidic disinfection by-products (DBPs) in Mediterranean chlorinated drinking water. Water Res. 36: 2596-2606. 


\section{Sources and levels of trihalomethanes in Suez bay water: Attaka power station (case study)}

Katranitsas, A.; Castritsi-Catharios, J. and Persne, G. (2003). The effects f a copper-based antifouling paint $\mathrm{n}$ mortality and enzymatic activity for a non-target marine organisms. Mar. Pollut., 46:1491-1494.

Krasner S.W.; McGuire, M.J.; Jacangelo, J.G.; Patania, N.L.; Reagan, K.M. and Aieta, E.M. (1989). The occurrence of disinfection by-products in US drinking water. J Am. Water Works Assoc., 81: 41-53.

Nebot, E.; Casanuva, J.F.; Casanuva, T.; Fern á ndez-Bastóm, M.M. and Sales, D. (2006). In situ experiment study for the optimization of chlorine dosage in seawater cooling systems. Appl. Therm. Eng., 26:1893-1900.

Parsons, T.R., Maita, Y. and Lalli, C.M. (1984) A Manual of Chemical and Biological Methods for Seawater Analysis. Pergamon Press, Oxford.

Rodriguez, M.J.; Serodes, J.B.; Levallois, P. and Proulx, F. (2007).Chlorinated disinfection by-products in drinking water according to source, treatment, season, and distribution location. J. Environ. Eng. Sci., 6: 355-365.

Saeed, T.; Khordagui, H. and Al-Hashash, H. (1999). Contribution of power/desalination plants to the levels of halogenated volatile liquid hydrocarbons in the coastal areas of Kuwait. Desalination, 121: 49-63.

Sakaguchi, I.; Shinshima, K.; Kawaratani, K. and Sugai,O. (1989).Control of mussel fouling with hot air injection and solid body abrasion (in Japanese); Denryoku Chuo Kenkyusho Hokoku (U89031),1-51.

Sugita, H.; Hayashi, K.; Asai, T.; Mitsuya, T.; Amanuma, K.; Maruyama, C. and Deguchi, Y. (1992). Spectrophotometric method for determination of total residual oxidants in seawater. Suisanzoshoku ,40:45-49.

Videla, H.A. (1995).Biofilms and corrosion interactions on stainless steel in seawater. Inter. Biodeterioration and Biodegradation,34:345-256.

Williams, D.T.; LeBel, G.L. and Benoit, F.M. (1997). Disinfection byproducts in Canadian drinking water. Chemosphere, 34: 299-316.

Wong, G.T.F. and Davidson, J.A. (1977). The fate of chlorine in seawater.Wat. Res.,11: 971978.

Soliman ,Y.A. and Yassin, M.A. ( 2007 ). Impact of marine fouling organisms relative to the water conditions of power station 1-Attack power station, Suez. J. Aquat. Biol. \& Fish.,11(3):1085-1098. 
مصادر ومستويات التراى هالو مثيثان فى مياه جونة السويس: محطة كهرباء عثاقة (دراسة حالة)

بسرى سليمان

المعهد القومى لعلوم البحار والمصايد

المستخلص

ينتج عن استخدام مادة الهييوكلوريت في مقاومة الحشف البحري في محطات القوى الكهربائية التي تعتمد على الى التى مياه البحر في تبريد التوربينات الى تكون مركبات التراى هالو م ئيّان شديدة الخطورة على البيئة البحرية في المياه الثاطئية امام هذه المحطات لذلك نم اختبار محطة كهرباء عناقة كحالة در اسية لأنها تستخدم نفس هذه المادة في مكافحة الحشف البحري حيث تم جمع عينات مياه شهريا خلال 2016-2017 من اربع مو اقع ثابتة على مدار العام وتم تحليل

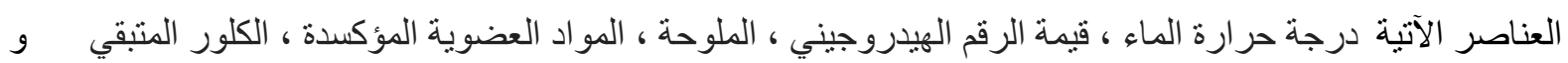

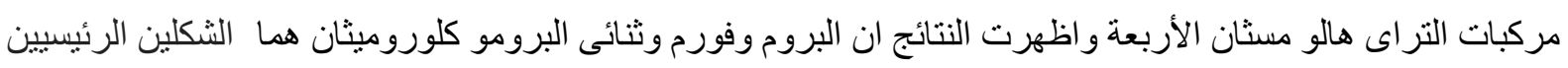
من مركبات التراى هالو مسثان الأربعة وقد تراوح مركب البروم وفورم بين 12.16 جزء في المليون و 237.25 جزء في المليون مع قيمة منوسطة قدر ها 77.23 جزء في المليون وبإجمالي سنوي قدره 926.76 جزء في في المليون ، في حين

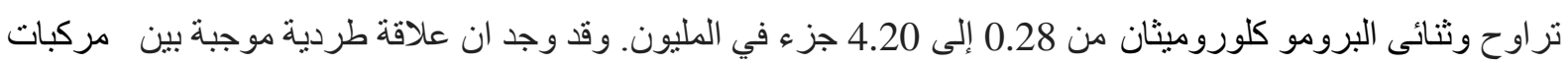

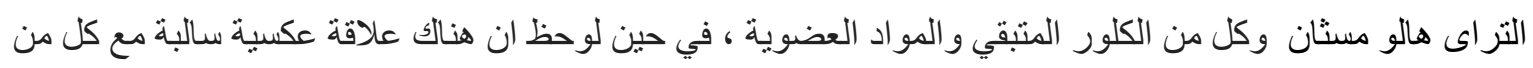
درجات حر ارة الماء وقيم الرقم الهيدروجيني هذا ولم بتم تسجيل اى علاقة بين مركبات التراى هالو مسثانفدرجة الملوحة. 
Sources and levels of trihalomethanes in Suez bay water: Attaka power station (case study) 